\title{
Indonesian Language Characteristics of Deaf Children and Implications for Literacy Skills
}

\author{
Nengah Arnawa ${ }^{1}$ \\ Faculty of Teacher Training and Education, University of PGRI Mahadewa Indonesia, Indonesia \\ Anak Agung Gde Alit Geria \\ Faculty of Teacher Training and Education, University of PGRI Mahadewa Indonesia, Indonesia \\ I Gusti Lanang Rai Arsana \\ Faculty of Teacher Training and Education, University of PGRI Mahadewa Indonesia, Indonesia
}

\begin{abstract}
This research aimed to reveal the characteristics of the Indonesian language in deaf children and the implications for their literacy skills. A qualitative approach was used on the subjects determined through purposive sampling. Data were collected by recording student performance portfolios, interviewing teachers, and observing video recordings. The data were analyzed descriptively and explanatively. The results showed that the Indonesian language for deaf children is limited, as seen through four ways. First, the vocabulary of deaf children is dominated by general words (hypernyms) and concrete references. Second, they do not use figures of speech or idioms, compound words, and terms. Third, their ability to form derivative words is still low. Fourth, they generally produce core and single sentences, and only a small part uses compound sentences. The main and single sentences have an inversion pattern, where the verb precedes the subject. Moreover, they fail to use linking between sentences, and the resulting discourse is a collection of separate sentences. The linguistic barriers resulted in a low effective reading speed of $33.04-68,30$ words per minute. This has implications for low literacy skills. Therefore, an intervention program is needed to improve the language skills of deaf children.
\end{abstract}

Index Terms — deaf children, literacy, Indonesian language characteristics, effective reading speed

\section{INTRODUCTION}

Literacy skills are necessary for a global society characterized by the rapid information flow that could be an opportunity or a threat. It is an opportunity when used for productive purposes and a threat when not utilized, left behind, and trapped by information flow. Responding to this social reality, Unesco (2003) showed the importance of literacy in developing the ability to seek, understand, evaluate, criticize, and manage information into useful knowledge.

Literacy is a fundamental and universal skill that indicates the human development index. It enables one to absorb, understand, and implement science, technology, art, and other life aspects published through various media. Therefore, literacy is an independent learning effort to increase the capacity of human resources that lasts a lifetime. However, this skill has not been mastered by most students in Indonesia. Various surveys by the Indonesian Ministry of Education and Culture (2017) show that the skills of children aged 9-14 in understanding and using reading materials are in the bottom ten worldwide. Therefore, the government established a national literacy movement program in 2017 to improve this condition. The fundamental literacy capacity is closely related to language reading and writing skills. The mastery of these two language skills influences other literacy dimensions. These include numeracy, science, digital literacy, religion or belief, as well as culture and citizenship. Therefore, it is urgently necessary to improve the students' language skills. This is where the strategic value of learning Indonesian, regional, and foreign languages at various levels and schools lies.

In the constitution, Indonesian is the official language of the state. It functions as a national identity and unifier of the nation, a means of implementing state administration and government. Also, it is an intercultural and inter-regional communication tool, an initiator of science and technology, and an introduction to education. According to the constitutional provisions, the Indonesian education system is the language of instruction and compulsory subjects at all types and levels of school. This position and function make the language the most important literacy tool, not least for deaf students. Therefore, the language skills of deaf children need improvement to support their literacy capacity. The improvement effort is effective when based on data about the characteristics of the students' language. This is consistent with the principles of language learning known as $\mathrm{i}+1$. It means that selecting and grading teaching materials is one level above the students' language competence (Baradja, 1990). This implies the importance of studying the characteristics of the Indonesian language of deaf children and their implications for literacy skills.

${ }^{1}$ Corresponding author. 


\section{THEORETICAL FRAMEWORK}

\section{A. Descriptive Linguistics}

The characteristic of the Indonesian language for deaf children is a contemporary portrait of its productive and receptive use. In this case, the characterization involves identifying aspects such as the vocabulary and grammar used by deaf children. Therefore, the descriptive linguistic theory is one of the references in this research. Descriptive linguistics studies language aspects based on authentic data (Gleason, 1970; Alwasilah, 1985; Arnawa, 2008). This theory is expected to naturally reveal the characteristics of the Indonesian language of deaf children. It examines aspects of a language synchronously, without relating them to historical variables and comparisons between languages. Furthermore, descriptive linguistic studies rely on the data of the language being studied. Therefore, the peculiarities of a language are expressed with this approach (Kridalaksana, 1993).

The object of descriptive linguistic study is the universal structure of a language formulated based on the repetitive patterns of the speech corpus collectivity. This means that descriptive linguistics abstracts the pattern of a particular language based on authentic data concretely used by the speaking community (Saussure, 1988), indicating that it relies on the natural data of a language. The use of natural data fundamentally explains linguistic processes (Sag, 1991). In this research, the characteristics of the language of deaf children were identified based on the real corpus it produced and mapped in Indonesian grammar. The results are language variations identified as characteristics of the language of deaf children, a principle consistent with the concept of parametric variation (Engdahl, 1991).

\section{B. Reading and Literacy Skills}

Literacy is closely related to reading skills. Lederberg et al. (2014) stated that reading skills are important for academic achievement and future life success, implying they need to be developed early. Therefore, it is necessary to have the vocabulary and linguistic competence to be a successful reader (Harris, 2015). Furthermore, the two aspects of being considered in reading are the skill of decoding linguistic symbols and the ability to understand their message. Understanding the message is insufficient, though it is mandatory in literacy activities. Therefore, creative and analytical reading skills are needed to support literacy activities (Oka, 1976; Baradja, 1976; Ingvalson et al., 2020).

Reading and literacy are cognitive skills resulting from the interaction between the nervous system and cultural experience. They are the ability to understand and use written information socially and individually (Hassanzadeh \& Nikkhoo, 2019). A literate reader constructs meaning to understand the world. In contrast, students with inadequate literacy development cannot participate maximally in classroom learning (Luckner et al., 2005). Therefore, reading and literacy are the essential skills needed by every student. This urgency gives an important position in teaching reading skills as an integral part of language learning (Triwiati \& Assjari, 2017). In this regard, Suhardi (1976) emphasized aspects that develop to improve reading skills. These include distinguishing the main from explanatory ideas, enriching vocabulary, interpreting messages, making inferences, and increasing reading interest.

The explanation illustrates the close relationship between reading and literacy activities. However, not every reading activity is identified as literacy, which exceeds the limits of reading as a cognitive activity. According to Nugrahani et al. (2020), the essence of literacy is the ability to process information and knowledge into life skills. Its emphasis on life skills shows that literacy is more applied than just a cognitive activity. Therefore, literacy activities in schools transcend reading comprehension activities to include real-life implementation of knowledge and understanding.

\section{Language Development of Deaf Children}

Deafness refers to the condition of a person with a hearing impairment. Technically, this term covers the condition of someone deaf and hard of hearing. A person is categorized as deaf when the hearing loss is 70 ISO Db, while it is called hearing loss when it is 35-69 Iso Db (Haenudin, 2013; National Council for Special Education, 2011). Hearing barriers impact a person's language development that begins by hearing the speech of the people around. Technically, this natural language acquisition is called implicit linguistics (Baradja, 1990).

Deaf children are slow in learning language due to limitations in absorbing linguistic exposure from their environment and often misinterpret linguistic input. The delays in language acquisition last until they enter school (Briggle, 2005). To overcome this obstacle, teachers should use varied learning strategies to improve the children's language experience. This delay results in literacy barriers that could be solved through language acquisition (Alothman, 2021). It is necessary to develop the deaf children's language and ability to understand information, despite having auditory barriers. Their language and understanding of the world around them could be developed using sign and written languages, as well as fingerspelling. Also, written language, reading, and writing should be encouraged in deaf children to comprehensively improve their word recognition and understanding.

Pratiwi (2011) stated that the language skills of deaf children affect their intellectual development, which is slower compared to children with hearing ability. Furthermore, hearing impairment inhibits thinking ability. The intellectual development barrier cannot be interpreted with the low IQ of deaf children. However, their intelligence cannot develop because of the language barrier they experience. Suparno (2001) showed the various aspects through which the language barrier experienced by deaf children could be observed. The aspects include poor vocabulary, difficulty in understanding expressions, figures of speech, idioms, abstract words, as well as long and complex sentences. These aspects are the focus of this research in describing the Indonesian language of deaf children. 


\section{RESEARCH METHODS}

\section{A. Research Design}

This research used a qualitative design. Strauss \& Corbin (2003) stated that qualitative research reveals and helps understand something behind the phenomenon. The observed phenomena are the construction and form of language produced by deaf children. The characteristics of the Indonesian language for deaf children were formulated based on the observed linguistic forms. They include vocabulary characteristics, sentence formation, and paragraphs.

\section{B. Research Subject}

This research took samples from SLB Negeri 1 Singaraja, SLB Negeri 1 Negara, and SLB Negeri 2 Denpasar, Special Schools (SLB) in Bali Province. The sample comprised 30 people determined non-randomly by purposive sampling based on two main criteria. The people selected had to be at the final level of education and a pure deaf child. In this case, the final level of education is six grades of special elementary school (SDLB) and third grades of Special Junior High School (SMPLB) and Special Senior High School (SMALB). Furthermore, pure deaf children did not have other obstacles. These criteria are important because there is a possibility of deaf children with multiple disabilities, such as mental retardation or visual impairment.

\section{Data Collection}

Data were collected by document recording, interviews, and observation. Documentation was conducted on the performance portfolio of student literacy activities. The documents included student essays, manuscripts of teacher assignments on various themes, such as participation in literacy competitions. Moreover, interviews were conducted with literacy teachers at each school to confirm the data recorded in the document. Observations were made on documentary video recordings at the school to obtain supporting data about the setting of the literacy activity space.

\section{Data Analysis}

Data were analyzed inductively, also known as the grounded theory approach (Strauss \& Corbin, 2003). The corpus of data obtained was classified based on the linguistic levels of vocabulary and grammatical. Furthermore, identification was conducted in each corpus group to produce the characteristics of the Indonesian language for deaf children. The generalization is expected to produce new concepts or develop pre-existing ones.

\section{RESULTS AND DisCUSSION}

\section{A. Characteristics of Deaf Children's Vocabulary}

(1) The vocabulary of deaf children is dominated by general words that relate to each other. One characteristic of the relationship between words is general-specific. Semantically, general and special words share the same meaning. Based on the data, the Indonesian vocabulary of deaf children is dominated by general words. In this study, deaf children were shown several pictures of flowers in turn. First, a picture of a rose was shown, where deaf children identified it as flowers. Second, a picture of Cempaka was shown and identified by the children as flowers. Third, a picture of frangipani was identified as a flower. Although their response was not wrong, it was less specific because the flower is a general word, while rose, Cempaka, and frangipani are specific words. Furthermore, pictures of grouper, tilapia, and cobs were shown, and all were identified as fish by the deaf children. Similarly, vests, shirts, and t-shirts were all identified as clothes. Therefore, the vocabulary of deaf children was dominated by general words.

(2) The vocabulary of deaf children represents the concrete meaning. Semantically, the vocabulary of a language is classified into concrete and abstract words. It is concrete when the word reference is related to the physical aspect, abstract when related to mental, conceptual, and emotional. The document recording results showed that $95.23 \%$ of the Indonesian vocabulary of deaf children are concrete words, while only $4.77 \%$ are abstract words.

TABLE 1

CLASSIFICATION AND FREQUENCY OF INDONESIAN VOCABULARY ON DEAF CHILDREN

\begin{tabular}{llcccc}
\hline \multirow{2}{*}{ NO } & \multirow{2}{*}{ CATEGORY } & \multicolumn{4}{c}{ Reference } \\
\cline { 3 - 6 } & & \multicolumn{2}{c}{ Concrete } & \multicolumn{3}{c}{ Abstract } \\
\cline { 3 - 6 } & noun & 203 & 28,47 & 23 & 3,23 \\
\hline 1 & Frequency & 45,16 & 8 & 1,12 \\
2. & Verb & 60 & 8,41 & 0 & 0 \\
3. & Adverb & 12 & 1,68 & 0 & 0 \\
4. & Pronoun & 61 & 8,56 & 3 & 0,42 \\
5. & adjective & 0 & 0 & 0 & 0 \\
6. & Particle & 21 & 2,95 & 0 & 0 \\
7. & Numerical & 679 & 95,23 & 34 & 4,77 \\
\hline
\end{tabular}

(3) Deaf children are less able to use the term. The term is part of the vocabulary, and a technical word used to describe the accuracy of thinking. The student performance documents did not show the use of technical terms by 
deaf children, even with the fishing technique. Furthermore, most of them cannot develop sentences with general terms, such as aspirations, self-taught, skilled, cultural, and wise.

(4) Deaf children are less able to use figurative language. Figurative is a variety of vocabulary in a language that expresses meaning using analogy or comparison. The deaf students' performance documents showed no use of figurative language. Furthermore, with the fishing technique, the deaf children were asked to develop sentences containing expressions such as long arms, thick face, stubbornness, and high-mindedness. Most of the children could not develop sentences with this technique.

(5) Deaf children are less able to use compound words. Compound words are a combination of two or more basic words that produce a new meaning. However, the construction cannot be inserted in other words. The deaf children's performance documents had little data on the use of compound words. From 713 vocabularies, only 4 $(0.56 \%)$ used compound words, such as kacamata (glasses), matahari (sun), orangtua (parents), and rumah sakit (hospital). The use of compound words is often replaced with their synonyms by deaf children, such as surat kabar (newspaper), replaced with koran (newspaper).

\section{B. Characteristics of the Grammatical Competence of Deaf Children}

(1) Morphology aspect

Indonesian has many affixes consisting of 8 prefixes, four infixes, 11 suffixes, four confixes, and nine combinations of affixes. However, only a few affixes are productively used by deaf children in the polymorphemic word-formation process, as shown in Table 2.

TABLE 2

TABULATION OF THE INDONESIAN AFFIXES USED BY DEAF CHILD

\begin{tabular}{|c|c|c|c|}
\hline No & Type & Affix & Sample data \\
\hline 1. & Prefix & $\begin{array}{l}\{\text { me.N- }\}, \\
\{\text { peN- }\}, \\
\{\text { ber- }\}, \\
\{\text { di- }\} \\
\{\text { ter- }\}\end{array}$ & $\begin{array}{l}\text { mengajak } \\
\text { perawat } \\
\text { bekerja, berbisik } \\
\text { digunakan } \\
\text { terbuat }\end{array}$ \\
\hline 2. & Suffix & $\begin{array}{l}\{-\operatorname{lah}\}, \\
\{-a n\},\end{array}$ & $\begin{array}{l}\text { sangatlah, } \\
\text { tumbuhan, sembarangan }\end{array}$ \\
\hline 3. & Affix combination & $\begin{array}{l}\{\mathrm{meN}-\mathrm{kan}\}, \\
\{\mathrm{meN}-\mathrm{i}\}\end{array}$ & $\begin{array}{l}\text { membersihkan, menjadikan } \\
\text { menyayangi }\end{array}$ \\
\hline 4. & Confix & $\begin{array}{l}\{\text { ke-an }\} \\
\{\text { per-an }\} \\
\{\text { peN-an }\}\end{array}$ & $\begin{array}{l}\text { kegunaan } \\
\text { perpustakaan } \\
\text { pengetahuan }\end{array}$ \\
\hline
\end{tabular}

(2) Syntax aspect

Data on sentence patterns for deaf children were taken from student performance documents comprising short stories, essay test answer sheets, and sentence development. From that source, 267 sentences were analyzed, 239 or $89.51 \%$ using single sentence patterns and 28 using compound sentence patterns. Of the 239 single-sentence patterns used, 183 had core-sentence patterns, such as Kerja di mana? Membersihkan kandangnya, Memandikan hewannya (Where do you work? Cleaning the cage, Bathing the animal). In contrast, 56 pieces had broad sentence patterns, such as Bekerja sebagai perawat Ibu Made; Merawat orang sakit Ibu Made; Terlihat penuh tempat sampahnya (Mrs. Made is Working as a nurse; Caring for the sick; Look! the trash bin full of trash). Furthermore, of the 56 compound sentences, 52 were equivalent compound sentences, such as Nyanyian daun kelapa tertiup angin, burung yang menari lengkap sudah indahnya (The singing of coconut leaves in the wind, birds that dance in full are beautiful). In comparison, 4 were dense compound sentences, such as Terbuat dari bata dan semen lantainya (the floor is made of brick and cement). The data shows the lack of use of multilevel and mixed compound sentences. Other interesting data often found are inversion patterns, such as Berapa tanggal lahir saya? Sudah makan aku. Belajar aku sekarang (What is my birthday? I have eaten. I am studying now).

(3) Discourse aspect

In preparing paragraphs, most deaf children are less able to use inter-sentence connectors. Paragraphs are formed by aligning sentences without conjunctions, such as;

(1) Ibu Made bekerja sebagai perawat. Ibu Made merawat orang sakit. Ibu made bekerja di rumah sakit umum. Setiap hari Ibu Made ke rumah sakit. Ibu made sangat ramah pada pasien.

(Mrs. Made works as a nurse. Mrs. Made takes care of the sick. Mrs. Made works in a public hospital. Every day Mrs. Made goes to the hospital. Mrs. Made is very patient-friendly).

(2) Lantainya terbuat dari bata dan semen. Dan Meja baca digunakan untuk apa! Membaca cerita pengetahuan dan ceita ilmu. Buku vokus buku tamu. Dan tidak boleh makan di perpustakaan. Tidak boleh berisik. Tidak boleh bicara yang aneh-aneh. Jam 09.10.

(The floor is made of brick and cement. And what is the reading desk used for! Read stories of knowledge and science stories. Guest book focus book. And you cannot eat in the library. Do not be noisy. Do not talk weirdly. at 09.10 am) 


\section{Effective Reading Speed}

Literacy is closely related to effective reading speed or its combination with comprehension. It is measured based on the average number of words read by deaf children per minute (called an A score in this research). Furthermore, reading comprehension is measured by the real score obtained by deaf children divided by the ideal maximum score (called score B). The A score is multiplied by the B score to determine the effective reading speed. Based on the grade level, the effective reading speed of deaf children is as follows. It is $33.04-37.04$ words per minute for sixth grades of elementary school and $37.04-45.43$ words per minute for third-grade junior high school students. Additionally, the effective reading speed of third-grade senior high school students is $45.12-68.30$ words per minute. The detailed data are presented in Table 3.

TABLE 3

EFFECTIVE READING SPEED DATA FOR DEAF CHILDREN

\begin{tabular}{|c|c|}
\hline No. Samples \& Grades & Effective Reading Speed /Minutes \\
\hline \multicolumn{2}{|c|}{ The sixth grade of elementary school students } \\
\hline 1. & 34,58 \\
\hline 2. & 33,48 \\
\hline 3. & 37,10 \\
\hline 4. & 33,04 \\
\hline 5. & 33,12 \\
\hline 6. & 37,04 \\
\hline 7. & 33,84 \\
\hline 8. & 33,67 \\
\hline 9. & 36,80 \\
\hline 10. & 35,98 \\
\hline \multicolumn{2}{|c|}{ The third-grade junior high school students } \\
\hline 11. & 43,75 \\
\hline 12. & 45,12 \\
\hline 13. & 37,04 \\
\hline 14. & 39,42 \\
\hline 15. & 41,52 \\
\hline 16. & 44,98 \\
\hline 17. & 39,90 \\
\hline 18. & 45,43 \\
\hline 19. & 39.48 \\
\hline 20. & 39,96 \\
\hline \multicolumn{2}{|c|}{ The third-grade senior high school students } \\
\hline 21. & 56,88 \\
\hline 22 . & 51,28 \\
\hline 23. & 65,79 \\
\hline 24. & 68,30 \\
\hline 25 . & 65,92 \\
\hline 26. & 45,12 \\
\hline 27. & 54,64 \\
\hline 28. & 65,79 \\
\hline 29. & 60,16 \\
\hline 30. & 64,88 \\
\hline
\end{tabular}

Table 3 shows that, of the 713 words used by deaf children, $679(95.23 \%)$ have concrete references, while only 34 $(4.77 \%)$ have abstract references. This means that the Indonesian vocabulary of deaf children is very limited due to their inability to absorb linguistic exposure in the surrounding environment (Baradja, 1990). The linguistic barrier impacts cognitive development, making deaf children unable to use abstract referenced words. Another characteristic that needs observation in the Indonesian vocabulary of deaf children is the use of general words (hypernyms). A hypernym is a word that semantically includes another more specific word (hyponym). The hypernym-hyponym relationship is hierarchical (Arnawa, 2008). Based on the data, most vocabularies of deaf children are hypernyms, indicating that they think more generic than specific. The specific thinking barriers are triggered by the limited linguistic input. Therefore, they cannot use figurative language, compound words, and technical terms.

Another characteristic observed from the use of the Indonesian language by deaf children is grammar, especially in morphology and syntax. Based on the typology, Indonesian is an agglutinative type with many affixes. However, deaf children only use active verb-forming prefixes and a few joining and confix affixes, implying limited linguistic competence. Linguistic competence is an abstract understanding of grammatical rules. It triggers the failure of deaf children to apply morphological rules in word formation. Moreover, in syntax, the Indonesian sentences produced by deaf children are core $(68.54 \%)$, expanded single (10.49\%), equivalent compound (19.48\%), and dense compound $(1.50 \%)$. The main and expanded single sentence patterns have an inversion structure, where the verb (predicate) precedes the subject. Examples are Makan sudah? Belajar aku; Mendengar dia (Have you eaten? I study; I Hear him). The dominant use of inverted sentence structures by deaf children proves that the semantic center lies in the verb (Arnawa, 2019). This is the trigger for the forwarding of verbs in the syntactic structure of the Indonesian language by deaf children. Furthermore, in discourse, deaf children cannot use linking between sentences. Cohesion and discursive coherence tools are also not used. As a result, the discourses composed seem to be a collection of separate sentences. 
The failure to use cohesion and coherence tools indicates the limited linguistic competence of deaf children. It is caused by their failure to absorb linguistic input. This language barrier inhibits cognitive development, resulting in logical barriers to connecting sentences. The language barrier in vocabulary, grammatical, and discursive reduces the effective reading speed. Based on data, the effective reading speed of deaf children at all levels is $33.04-68,30$ words per minute. This figure is below the reference rate for normal children in the same age group, $80-245$ words per minute. Consequently, this significant reading speed barrier hampers the literacy skills of deaf children. Therefore, it is necessary to manage literacy texts consistent with the linguistic characteristics and the effective reading speed of deaf children.

\section{CONCLUSION}

The limitations of the Indonesian language skills of deaf children hinder their literacy skills. These barriers are triggered by the vocabulary dominated by general words with no specific meanings. Furthermore, literacy failure is triggered by the limitations of deaf children in understanding abstract vocabulary. As a result, they cannot understand the abstract messages from the text they read. Literacy barriers for deaf children are also triggered by limited grammatical mastery of morphology, syntax, and discursive devices. Additionally, the limited linguistic (grammatical) competence has implications for failing to understand the text message. As a result, these linguistic limitations reduce the effective reading speed of deaf children. When this condition is not properly intervened, they would lose information compared to normal children. Furthermore, it is necessary to ensure that their literacy materials are adapted to their linguistic competence. Literacy texts for deaf children should be shorter, with brief sentences and general vocabulary. Also, technical terms should be explained using common words for deaf children to understand.

\section{ACKNOWLEDGEMENTS}

The authors are grateful to the Directorate of Research and Community Service, Directorate General of Higher Education, Ministry of Education, Culture, Research and Technology of the Republic of Indonesia for funding this research. The gratitude is also conveyed to the teachers, principals, and students who were the samples of this research.

\section{REFERENCES}

[1] Alothman, A.A. (2021). Language and Literacy of Deaf Children. Psychology and Education, 58(1), 799 - 819. Retrieved August 21, 2021 from https://doi.org/10.17762/pae.v58i1.832

[2] Alwasilah, A. Chaedar. (1985). Beberapa Madhab dan Dikotomi Teori Linguistik. Bandung : Angkasa.

[3] Arnawa, N. (2008). Wawasan Linguistik dan Pengajaran Bahasa. Denpasar: Plawa Sari.

[4] Arnawa, N. (2019). Personification in cecimpedan: the semantic structure of the tradition of Balinese children. Opcion 35(89), 896-912. Retrieved August 1, 2019 from https://www.produccioncientificaluz.org/index.php/opcion/article/view/24449/0

[5] Baradja, M.F. (1976). Membaca. Jurnal Pengajaran Bahasa dan Sastra, 2(1), 2 - 9.

[6] Baradja, M.F. (1990). Kapita Selekta Pengajaran Bahasa. Malang : IKIP Malang Press.

[7] Briggle, S.J. (2005). Language and Literacy Development in Children Who Are Deaf or Hearing Impaired. Kappa Delta pi Record, 68 - 71. Retrieved August 21, 2021 from https://files.eric.ed.gov/fulltext/EJ683441.pdf

[8] Engdahl, E. (1991). Parametric Variation. In Natural Language and Speech (Veltman, eds), 85 - 94. New York: SpringerVerlag.

[9] Gleason, H.A. (1970). An Introduction to Descriptive Linguistics. London: Holt.

[10] Harris, M. (2015). The Impact of New Technologies on the Literacy Attainment of Deaf Children. Top Lang Disorder, 35(2), 120 - 132. Retrieved August 21, 2021 from http://doi.org/101097/TLD. 0000000000000052

[11] Haenudin. (2013). Pendidikan Anak Berkebutuhan Khusus Tunarungu. Jakarta: PT. Luxima Metro Media.

[12] Hassanzadeh, S. and Nikkhoo, F. (2019). Reading Literacy Development of Deaf Students in Special Schools in Iran. International Journal of Special Education, 34(1), 245 - 254. Retrieved August 21, 2021 from https://files.eric.ed.gov/fulltext/EJ1237148.pdf

[13] Ingvalson, E.M; Grieco-Calub, T.M; Perry, L.K; and VanDam, M. (2020). Rethinking Emergent Literacy in Children with Hearing Loss. Frontier in Psychology, Vol. 11, $1-$ 12. Retrieved August 21, 2021 from http://doi.org/10.3389/fpsyg.2020.00039

[14] Kemendikbud. (2017). Panduan Gerakan Literasi Nasional. Retrieved August $14, \quad 2019 \quad$ from https://gln.kemdikbud.go.id/glnsite/wp-content/uploads/2017/08/panduan-gln.pdf

[15] Kridalaksana, H. (1993). Kamus Linguistik. Jakarta: Gramedia.

[16] Lederberg, A.R; E.M. Miller; S.R. Easterbrooks; C. M. Connor. (2014). Foundations for Literacy: An Early Literacy Intervention for Deaf and Hard-of-Hearing Children. Journal of Deaf Studies and Deaf Education, 9(4), 438 - 455. Retrieved August 21, 2021 from http://doi.org/10.10903/deafed/enu0202

[17] Luckner, J.L., Sebald, A.M., Cooney J., and Muir, S.G. (2005). An Examination of the Evidence-Based Literacy Research in Deaf Education. American Annals of the Deaf, 150 (5), 443 - 456. Retrieved August 21, 2021 from http://doi.org/10.1353/aad.2006.0008

[18] National Council for Special Education. (2011). The Education of Deaf and Hard of Hearing Children in Ireland. Retrieved August 21, 2021 from https://ncse.ie/wp-content/uploads/2014/09/DeafEducationReport.pdf 
[19] Nugrahani, F; Imron, A; and Widayati, M. (2020). Gerakan Literasi Sekolah Berbasis Kearifal Lokal dan Kontribusinya bagi Pendidikan Karakter. Jurnal Widyaprana, 48 (1), 50 - 64 . Retrieved July 17,2021 https://www.widyaparwa.com/index.php/widyaparwa/article/download/438/pdf_1

[20] Oka, I G.N. (1976). Membaca Kreatif. Jurnal Pengajaran Bahasa dan Sastra, 2 (2), 2 - 7.

[21] Pratiwi, M.M.S. (2011). Psikologi Anak berkebutuhan Khusus. Semarang: Semarang University Press.

[22] Sag, Ivan A. (1991) Linguistic Theory and Natural Language Processing. In Natural Language and Speech (Veltman, eds), 69 - 83. New York: Springer-Verlag.

[23] Saussure, F. de. (1988). Pengantar Linguistik Umum. Yogyakarta: Gadja Mada University Press.

[24] Suhardi, B. (1976). Pelajaran Membaca. Jurnal Pengajaran Bahasa dan Satra, 1(5), 33 - 41.

[25] Suparno. (2001). Pendidikan Anak Tunarungu (Pendekatan Orthodidaktik). Yogyakarta: Universitas Negeri Yogyakarta Press.

[26] Strauss, A. And Corbin J. (2003). Dasar-Dasar Penelitian Kualitatif. Yogyakarta: Pustaka Pelajar.

[27] Triwiati, R. and Assjari, M. (2017). Program Literasi Sekolah untuk Meningkatkan Kemampuan Membaca Siswa Tunanetra di SLB Cimahi. Jurnal Asesmen dan Intervensi Anak Berkebutuhan Khusus, 8(2), 51 - 56. Retrieved June 18, 2019 from https://ejournal.upi.edu/index.php/jassi/article/view/9697

[28] Unesco. (2003). The Prague Declaration: Towards an Information Literate Society. Retrieved August 21, 2021 from http://www.unesco.org/new/fileadmin/MULTIMEDIA/HQ/CI/CI/pdf/PragueDeclaration.pdf

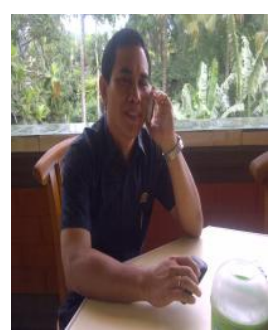

Nengah Arnawa was born in Jinengdalem, Singaraja, Bali, Indonesia on December $24^{\text {th }}, 1965$. He earned his doctorate degree in 2005 from Udayana University Denpasar, Bali, Indonesia. Since November $1^{\text {st }}, 2002$ he attained associate professor. His areas of interest are semantics, pragmatics and the philosophy of language. His articles are Meaning Truth Explication Language Philosophy: A Multicultural Communication Dimension (2015); Children Indirect Speech Acts at Ages 18-24 Month Old: A Case Study on Indonesian Language Acquisition by Balinese Children (2016); Shift of Balinese Language Vocabulary of Agriculture: a study on anthropological linguistics (2016); Interpretasi Pragmatis Analogis Metafora Bahasa Bali (2016); Struktur Semantik dan Pembatasan Gramatikal: Studi Kasus pada Kalimat Bahasa Indonesia (2016); The Implementation of Natural Semantic Metalanguage and Semantic Filed in Language Teaching: A Case Study (2017); Cecimpedan: Semantic-cognitive Process on Balinese Children (2017); The Use of Modality Markers to Perform Hegemony Politeness in Using Balinese Language: A Case Study on Awig-Awig (2017); Balinese Hegemonic Politness in Awig-Awig of Desa Pakraman (2018); Pragma-Gramatikal Kesantunan Hegemonis Bahasa Bali dalam Awig-Awig (2018); Perspektif Semantik Universal pada Pengajaran Kosakata Bahasa Indonesia di Sekolah Dasar Kelas Rendah (2018); Problematika Kurikulum Generik Pelajaran Bahasa Bali (2019);The Implementation of School Literacy Program for Blind Students at Special in Bali Province (2020); Metaphors about Balinese Women: From Semantic Analysis to Cultural Pragmatic Interpretations (2021). Since 2014, he has been a member of the Local Languages Researcher (APBL).

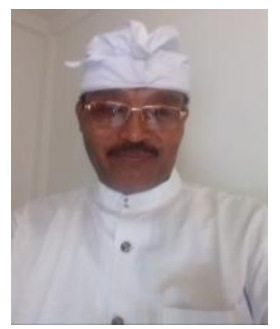

Anak Agung Gde Alit Geria, M.Si., is a lecturer at the Faculty of Teacher Training and Education, University of PGRI Mahadewa Indonesia. He was born in Br. Petak, Petak Kaja Village Gianyar Bali on April, 21th 1963. He completed his bachelor degree [Balinese Language and Literature] at the Faculty of Literature, Udayana University in 1987. He reached Master of Cultural Studies at Udayana University Postgraduate Program in 2004. He pursued his doctoral degree in linguistics [Concentration of Literary Discourse] at Udayana University Postgraduate Program in 2012, with the dissertation title "Siwa-Buddha Discourse in Kakawin Nilacandra: Reception Analysis". He has worked in the Manuscript section at the National Library of Indonesia Jakarta [1990--1996], as well as an Extraordinary Lecturer at the Faculty of Literature, University of Indonesia Jakarta [1990--1996]. Previously worked at the Bali Provincial Library [1997--2005] and at the Art Center [2005--2006]. Since 2006, he became lecturer at Faculty of Teacher Training and Education, University of PGRI Mahadewa Indonesia. Perseverance in the field of manuscripts has always been cultivated until now. A number of lontars have been researched, cataloged, transliterated, translated, and even studied. Books that have been published include: Geguritan Uwug Kengetan [2014], Musala Parwa [2015], Prastanika Parwa [2016], Bhomakawya [2017], Wacana Siwa-Buddha dalam Kakawin Nilacandra [2018], Ala-ayuning Dina mwah Sasih [2018], Tutur Sundhari Bungkah [2019], Geguritan Ni Dyah Anggreni [2019], Kakawin Nilacandra Abad XX [2019], dan Singhalangghyala Parwa [2020]. In additon, he also teaches Manuscript Studies at the Postgraduate Study Program of Religious Literature and Balinese Language Education at UHN IGB Sugriwa Denpasar since 2013. In the midst of his activities as a lecturer, he also active in writing and working in the field of manuscript as well as attending scientific meeting both nationally and internationally.

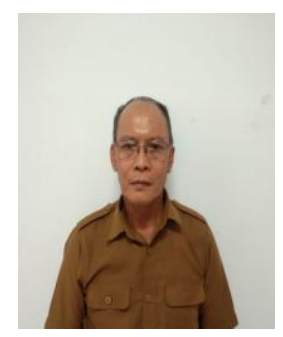

I Gusti Lanang Rai Arsana was born in Padang Tegal, Ubud, Gianyar, Bali, Indonesia on October $23^{\text {rd }}, 1960$. He earned his master degree in 2008 from University of Pendidikan Ganesha, Bali, Indonesia. His areas of interest are research and educational evaluation. Since October $1^{\text {st }}, 2023$, he attained associate professor. He has produced some articles, such as: Model Layanan Life Skills Counselling Berlandaskan Tri Hita Karana pada Warga Belajar di Kabupaten Bangli, Klungkung dan Karangasam Provinsi Bali (2014), The Implementation Of School Literacy Program (2020), Peran Konselor dalam Membimbing Siswa Menuju Perguruan Tinggi yang Tepat Sesuai Minat dan Bakat (2021), Pemetaan Gerakan Literasi pada Sekolah Luar Biasa di Provinsi Bali (2021). Since 2014 he has been a member of the Indonesian Lecturer Association. 